\title{
Digital Preservation Policies of the Institutional Repositories at Brazilian Federal Universities
}

\begin{abstract}
Purpose - This article aims to verify the implementation of digital preservation policies at the institutional repositories of Brazilian Federal Universities.

Design/methodology/approach - The methodology used involved the verification of the information available in the Directory of Open Access Repositories (OpenDOAR) and on the websites of the institutional repositories, in order to confirm the existence of published digital preservation policies. We used a sample of the 26 institutional repositories of Brazilian Federal Universities registered with OpenDOAR, which represents $68 \%$ of these repositories.

Findings - The main conclusion is that the institutional repositories of these universities do not have any published digital preservation policies, even though some repositories state their intention of preserving digital material in their institutional information policy.

Originality/value - The stakeholders of institutional repositories need to implement a programme to guide their activities to preserve digital materials in the long-term. In fact, similarly to examples worldwide, this programme should take the form of an institutional commitment outlined in a digital preservation policy. Institutional repositories at Brazilian Federal Universities still have a long way to go in order to guarantee access to digital materials in the longterm.
\end{abstract}

Keywords - Institutional Repositories, OpenDOAR, Digital preservation policy, Brazil

Paper type - Research paper

\section{Introduction}

Institutional repositories (IRs) are complex structures that depend on political, cultural and technological aspects and mirror the organisation's intellectual production. Their main function is, therefore, to ensure worldwide availability of digital materials and, according to Rodrigues (2009), to consider their long-term preservation. In the case of a university: “...at the most basic and fundamental level, an institutional repository is a recognition that the intellectual life and scholarship of our universities will increasingly be represented, documented, and shared in digital form, and that a primary responsibility of our universities is to exercise stewardship over these riches: both to make them available and to preserve them" (Lynch, 2003, p. 2). To this end, an IR should clearly state its intention of preservation by means of an explicit published digital preservation policy. This should be done in such a way that depositors could access and understand the implications of the adopted policy. Although not all IRs possess or intend to implement a commitment to digital preservation and some digital materials may not need to be preserved. This should be made clear to depositors (McGovern and McKay, 2008).

There are several guidelines on the definition of digital preservation policies which focus on different topics, ranging from preservation planning, to rights and restriction management, sustainability planning, among others. In 2008, the Joint Information Systems Committee (JISC) funded a study on the development of a digital preservation institutional policy for universities in the United Kingdom (Beagrie et al., 2008). The InterPARES project, in partnership with the International Council on Archives, also developed a series of educational resources on preservation for practitioners who work with digital registers (InterPARES 3, 2009). The Catalogue of Policy Elements is part of the policy framework in the SCAPE (SCLable Preservation 
Environment) project. It was developed to make it easier for organisations to create their own preservation policy, thus helping them to prepare for the automation of these policies (Sierman et al., 2014). The Directory of Open Access Repositories (OpenDOAR) has a tool to formulate and submit a set of policies for an open access repository. Both the JISC and the InterPARES present approaches that specify clauses, which help structure a digital preservation policy. The first, however, focuses on a more structured model, whereas the second develops a more general understanding of the concepts of this type policy. The SCAPE defines elements that can be of use, as far as the preparation of clauses is concerned, and highlights the fact that using all the proposed items is not mandatory. The OpenDOAR tool aims to help institutions in the formulation and presentation of a set of policies for their repositories, by considering some of the basic principles of the open access movement.

Within this context, this paper aims to examine the implementation of digital preservation policies in the 26 IRs of Brazilian Federal Universities registered with OpenDOAR, which represents $68 \%$ of the total (38) of these repositories in Brazil. The methodology used involved the verification of the information available in the OpenDOAR and on the websites of the IRs to confirm the existence of published digital preservation policies.

\section{The Directory of Open Access Repositories (DOAR) and the Brazilian Initiative}

The OpenDOAR project, launched in 2006 as a joint collaboration between the University of Nottingham in the UK and the University of Lund in Sweden, was developed to support the movement towards open access to research information. Both the relevance and coverage of the service have been demonstrated by the importance of its original funders, namely the Open Society Foundation (OSF), the JISC, the Research Libraries UK (RLUK) and the Scholarly Publishing and Academic Resources Coalition (SPARC) (Hubbard and Björnshauge, 2006).

The team in charge of the project (OpenDOAR, 2014 a) considered that repositories need to be classified according to information on their policies concerning "[...] tagging peer-reviewed material/non-peerreviewed material, their subject coverage, the constituency they draw on for content, their collection and preservation policies, etc." The truth is that this information further improves their visibility and the ability to use the material that they store. The OpenDOAR was set up to improve and sustain the academic and research activities of the worldwide community in a consistent way. The OpenDOAR, run by the SHERPA service, makes a wide-range and authoritative list of institutional and subject-based repositories available. It collects and provides information on sites that agree with the concept of open access to scientific literature, and aims to achieve the following objectives (OpenDOAR, 2014a):

○ "Survey the growing field of academic open access research repositories and categorise them in terms of locale, content, and other measures. 
- Produce a descriptive list of open access repositories of relevance to academic research.

- Provide a comprehensive \& authoritative list for end users wishing to find particular types of, or specific repositories.

- Deliver a comprehensive, structured and maintained list with a clear update and self-regulation protocols to enable development of the list.

- Play a prominent international role in the organisation of and access to open access repository services.

○ Support open access outreach and advocacy endeavours within institutions and globally".

The OpenDOAR surveyed repositories in early 2006 and came to the conclusion that many repositories did not have a published public policy for access and use of stored resources. Moreover, they did not have a policy for the submission of objects for long-term preservation. It was not by chance that in 2007 the Census of institutional repositories in the United States revealed that digital preservation in IRs was still in its infancy (Markey et al., 2007). This situation showed that the visibility of the intellectual production of an institution was in trouble. Consequently, the OpenDOAR developed a tool to help stakeholders in the drawing up and presentation of policies for their repositories. The tool was built taking into account some basic aims of the open access movement and the optimisation of the use of a repository. The tool does, however, not generate any policy statements for legal purposes. The focus is on the simplification of language for repository users and if legal statements need to be published, the tool has an option to link to an external website for this purpose. It is divided into five policy categories: metadata policy, data policy, content policy and submission policy, even though all these categories have a close connection with preservation in a broad sense, since "a preservation policy cannot be seen in isolation from other policies" (OpenDOAR, 2014b).

In September 2005, the Instituto Brasileiro de Informação em Ciência e Tecnologia [Brazilian Institute for Information in Science and Technology] (IBICT) published the Manifesto Brasileiro de Apoio ao Acesso Livre à Informação Científica [Brazilian Manifesto in Support for Open Access to Scientific Information]. Among other statements, this document advised Brazilian academic institutions to be committed to creating institutional and thematic repositories in accordance with the open access paradigm (IBICT, 2005). As a consequence, the IBICT developed two initiatives at different levels, both in legal and infrastructure terms. At a legal level, the IBICT cooperated in the drawing up of a bill in the Brazilian Federal Senate, under number 387/2011, to compel all higher education public institutions, in addition to institutional research centres, to build their IRs (Rollemberg, 2011). In terms of infrastructure, the initiative included the donation of dozens of servers to the universities. In return, universities would set up their repositories and adopt an institutional information policy (IIP) - a model that contemplates the open access self-archiving institutional mandate formulated by Harnad (2006) - in order to populate the repository and preserve scientific production (Kuramoto, 2009).

\section{Checking the Published Preservation Policies at Brazilian Federal Universities}


In this section we summarise the results of the double verification of digital preservation policies at Brazilian Federal Universities in the OpenDOAR and on the IR websites. With regard to the Institutional Information Policies to be drawn up by universities, it is important to note that the concern for preservation should be stated as the first clause of the IIP framework. The findings and comments are as follows (ordered by the date of the IIP publication):

- Universidade Tecnológica Federal do Paraná (UTFPR): the last OpenDOAR review of its policies took place in October 2013 and the preservation description is stated as explicitly undefined. An IIP was published in December 2009 on the repository website (UFTPR, 2009). The purpose of the policy is to facilitate preservation. It considers the formulation of a specific policy to preserve the stored material, but it does not provide any guidelines to follow on how to plan the preservation.

- Universidade Federal da Bahia (UFBA): the last OpenDOAR review of the repository policies took place in January 2012, also had its status classified as explicitly undefined (UFBA, 2010). The IIP repository conveyed a general intention to preserve the scientific production of the university, however did not specify the means to put it into practice.

- Universidade Federal da Grande Dourados (UFGD): the last OpenDOAR review of the IR took place in 2013. Similar to the previously mentioned repositories, the status of its preservation policy was graded as explicitly undefined (UFGD, 2010). An IIP was published as a mere statement of intent, as it was not formulated as an official document. It is, however, important to mention that the preservation of scientific and technical production has become a general concern for this repository.

- Universidade Federal de Pelotas (UFPEL): the last OpenDOAR review of the repository policies was performed in May 2013 and its preservation policy has not yet been analysed. The university IIP was issued in June 2010 and it defined the IR as an information system to store, preserve, organise and spread the scholarly production of the institution. Furthermore, Articles 7 and 8 of this IIP established the responsibilities and prerogatives for the management staff. As defined in the IIP, they must deal with metadata, formats, migration and content preservation with caution (UFPEL, 2010). Meanwhile, no other published policy related to the development of a preservation programme has been found in the scope of this study.

- Universidade Federal do Rio Grande do Sul (UFRGS), the last review of its policies in the OpenDOAR took place in July 2010 and the preservation description is still currently stated as explicitly undefined (UFRGS, 2010). Notwithstanding, this university published an IIP in October 2010, in which there is a concern regarding the digital preservation of the institutional memory in the long-term. In spite of stating this concern, nothing significant has been done in order to implement the necessary changes, i.e., there is still no digital preservation programme. Something that should be 
noted is that this IIP outlines a section for metadata requirements, which is a fundamental element of digital preservation, however the definition of the metadata typology was of the responsibility of the stakeholders of this repository. Yet, no specific policy has been drawn up to support the team and users of the repository.

- Universidade Federal do Rio Grande do Norte (UFRN): the last OpenDOAR review of the repository policies, performed in March 2011 found a similar situation to the abovementioned repositories and the IR is also categorised as having an explicitly undefined status (UFRN, 2010). The university IIP outlines the need to preserve technical and scientific institutional production but it does not specify how it could be applied.

- Universidade Federal de Sergipe (UFS): the last OpenDOAR review of the IR was performed in January 2013 and the status of the preservation policy was classified as explicitly undefined (UFS, 2010). The 5th article of the Free Access Policy of the UFS Scientific Production states that authors must authorise the preservation enabled by the repository. Yet, nothing is said about the way this could be accomplished.

- Universidade Federal dos Vales do Jequitinhonha e Mucuri (UFVJM): the last OpenDOAR review dates from May 2011 and the status of the preservation policy was classified as explicitly undefined. The Operational Policy of the Institutional Repository at this university was regulated in 2010 (UFVJM, 2010), and is similar to initiatives defined by other universitie as an IIP, although it has a different name. It also considers preservation as one of its goals, as stated in Article 2, but it does not specify how this preservation could occur.

- Universidade Federal do Rio Grande (FURG): the last OpenDOAR review took place in June 2011. As in the previous cases, the preservation description is stated as explicitly undefined. Its IIP took into consideration the need to preserve the intellectual production of the institution and assigned the maintenance of a set of data, which was meant to be updated and organised in order to guarantee its digital preservation to the management committee (FURG, 2011). Nothing else has been done in terms of digital preservation.

- Universidade Federal do Ceará (UFC): received its most recent OpenDOAR review in September 2014 and the status of the preservation policy was classified as explicitly undefined. The university IIP considers the need to preserve the technical and scientific institutional production, and in Article 3 there is a single paragraph stating that authors must allow institutions to preserve their scientific output in accordance with conditions defined by the Authorisation Agreement. A template of this agreement can be retrieved from the repository homepage (UFC, 2011). It is important to mention though that the policy does not specify the means by which the preservation would be achieved. 
- Universidade Federal de Lavras (UFLA): the last OpenDOAR review of its policies was in January 2013 and the status of its preservation policy still appears as not found. In November 2012, an IIP, which states the intention to preserve the scholarly production of the university, was published on the repository website (UFLA, 2012), however it does not include any specific policy or programme which would allow for this preservation policy to be implemented.

- Universidade Federal de Ouro Preto (UFOP): the last OpenDOAR review on the repository website of the IR was in March 2015 and the preservation policy status was stated as explicitly undefined. The repository IIP acknowledges the leading role of digital preservation (UFOP, 2013), but the university did not develop a digital preservation policy.

- Universidade Federal do Recôncavo da Bahia (UFRB): the last OpenDOAR review of the repository policies took place in May 2011 and the preservation policy was defined as unknown. The university's Technical and Scientific Information Policy considers the need to maintain technological and scientific institutional production. Whereas preservation per se was not actually specified, Article 12 of the previously mentioned policy foresees the creation of complementary standards to establish a digital preservation policy (UFRB, 2013).

- Universidade de Brasilia (UNB): the last review of repository policies was in January 2013 and the status of the preservation policy was also considered as explicitly undefined. An IIP was published in October 2013 on the repository website, aimed at preserving the scientific production of the university (UNB, 2013), however it did not define how this would actually take place.

The following repositories do not have a formal IIP:

- Universidade Federal de Minas Gerais (UFMG): there are two records on the OpenDOAR (ID 2907 and ID 3457). The last OpenDOAR review of the first ID was performed in November 2013 and of the second in August 2015. In both records the status of the preservation policies is currently specified as being not found. A repository policy was published on the repository website, and even though the policy foresees the preservation of the relevant material as well as all kinds of digital formats (UFMG, 2015), no digital preservation policy was explicitly indicated.

- Universidade Federal do Pará (UFPA): the last review was in October 2012 and the preservation policy status was stated as explicitly undefined. Even though it does not have an IIP, the repository webpage has a section entitled Policies, under which the issue of levels of preservation is addressed. This covers topics such as: bit preservation, database backup, and persistent identifiers (UFPA, 2015). However, this section is limited to descriptions of concepts, as they are understood by the repository staff. 
The following repositories do not have an IIP. As the other repositories listed above, they do not have a preservation policy registered with DOAR nor is it published on their homepage:

- IR of the Universidade Federal do Espírito Santo (UFES, 2015).

- IR of the Universidade Federal Fluminense (UFF, 2015).

- IR of the Universidade Federal de Goiás (UFG, 2015).

- IR of the Universidade Federal do Maranhão (UFMA, 2015).

- IR of the Universidade Federal do Mato Grosso do Sul (UFMS, 2015).

- IR of the Universidade Federal da Paraíba (UFPB, 2015).

- IR of the Universidade Federal do Paraná (UFPR, 2015).

- IR of the Universidade Federal de Pernambuco (UFPE, 2015).

- IR of the Universidade Federal de Santa Catarina (UFSC, 2015).

- IR of the Universidade Federal de Uberlândia (UFU, 2015).

The statuses for all IRs in the OpenDOAR are summarised in table 1.

Table 1: The preservation policy status in the DOAR

\begin{tabular}{|c|c|c|}
\hline Institutional Repository & Preservation policy & Last reviewed \\
\hline UFRGS & Explicitly undefined & 2010-07-14 \\
\hline FURG & Explicitly undefined & $2011-06-15$ \\
\hline UFPEL & Not yet analyzed & $2013-05-29$ \\
\hline UFSC & Explicitly undefined & $2012-04-25$ \\
\hline UTFPR & Explicitly undefined & 2013-10-18 \\
\hline UFPR & Not stated & $2008-05-12$ \\
\hline UFMG & Not found & 2013-11-19 \\
\hline UFLA & Not found & $2013-01-25$ \\
\hline UFU & Explicitly undefined & 2012-01-09 \\
\hline UFOP & Explicitly undefined & $2015-03-18$ \\
\hline UFVJM & Explicitly undefined & 2011-05-04 \\
\hline UFF & Explicitly undefined & 2014-08-21 \\
\hline UFES & Explicitly undefined & 2014-08-21 \\
\hline UFGD & Explicitly undefined & $2012-08-30$ \\
\hline UFG & Explicitly undefined & $2015-03-13$ \\
\hline UFMS & Explicitly undefined & $2012-01-10$ \\
\hline
\end{tabular}




\begin{tabular}{|l|l|l|}
\hline UNB & Explicitly undefined & $2013-01-21$ \\
\hline UFRB & Unknown & $2013-08-22$ \\
\hline UFBA & Explicitly undefined & $2012-01-09$ \\
\hline UFS & Explicitly undefined & $2013-01-10$ \\
\hline UFPE & Explicitly undefined & $2013-10-25$ \\
\hline UFPB & Not stated & $2014-02-06$ \\
\hline UFRN & Explicitly undefined & $2011-03-23$ \\
\hline UFC & Explicitly undefined & $2014-09-17$ \\
\hline UFMA & Explicitly undefined & $2012-04-25$ \\
\hline UFPA & Explicitly undefined & $2012-10-04$ \\
\hline
\end{tabular}

The last reviewed status in the DOAR had been checked until june 2015.

As demonstrated, The IRs at Brazilian Federal universities registered with the OpenDOAR do not have any preservation policies, even though all the repositories that implemented the IBICT IIP framework declare the intention to preserve digital materials. Regarding the publication of their IIP, of the 26 Brazilian Federal Universities analysed, 14 have published an IIP since 2009: one in 2009; seven in 2010; two in 2011; one in 2012; three in 2013. There are two universities, which do not have a formal published IIP and ten that have no IIP published at all. Taking into account previous studies and in spite of the Brazilian effort to help universities setting up IRs, namely through IBICT, only 12 federal universities have developed such a policy. Furthermore, studies have proved that a digital preservation culture is still scarce (Ribeiro, 2012; Medeiros and Ferreira, 2014). This research shows that the number of federal universities which have an explicit policy to preserve digital collections in their IIPs is still low: 14 (54\% of the sample) have a defined and published IIP, but they do not address the problem of digital preservation in depth. This represents a very slow evolution since 2009.

In order to implement these intentions, investment in the training of the staff that run the repository needs to occur, as well as sustainable funding:

"Since the IR is still in a stage of development at many institutions, lack of sustainable funding and adequate staffing could present an obstacle in implementing successful digital preservation programs. It will be important to address these sustainability issues as part of the planning process for building a digital preservation program" (Li and Banach, 2011).

An excellent way of starting the training would be the study of the InterPARES 3 (2009) document, mainly of module 2, entitled, Developing Policy and Procedures for Digital Preservation. Universities should also draw up, in collaboration with representatives of the users' community, a digital preservation policy. To that 
purpose, the catalogue of the SCAPE project (Sierman et al., 2014) - which takes into account examples of digital preservation policies developed at other Brazilian institutions -, the model of digital preservation policies for higher education institutions (Beagrie et al., 2008) and the digital preservation framework of the Ohio State University Library (Noonan, 2014) can be quite useful. These last two frameworks are based on dozens of repositories in Europe and in the USA. The resulting models present features that can be adjusted to the reality of the Brazilian repositories. These elements are crucial to the involvement of (Brazilian) institutions in issues related to digital preservation. Moreover, the institutions should be mentioned and referred to in the repository on the website.

\section{Conclusion}

IRs are one of the roads - namely the Green Road - mentioned by the Budapest Open Access Initiative for open access to scientific literature (BOAI, 2012). When universities create an IR, they are not only allowing access to their intellectual output, but also intend to preserve content on a long-term basis. Such repositories “[...] can include preprints and post-prints of journal articles, theses and dissertations, course materials, databases, data files, audio and video files, institutional records, or digitised special collections from the library" (Suber, 2013). Thus, the stakeholders of the IRs require a programme to guide their activities to preserve these materials in the long-term. In addition, this programme should be considered as a commitment on behalf of the institution in the form of a digital preservation policy.

In conclusion, the IRs at Brazilian Federal universities registered at the OpenDOAR do not have any preservation policies, even though all the repositories that have implemented the IBICT IIP framework state their intention of preserving digital materials. Universities have made an effort to give visibility to their repositories by registering them with the OpenDOAR. Yet these teaching institutions do not seem to give due importance to the DOAR and the sets of policies it provides. A literature research on the websites of the repositories revealed that there are not any digital preservation policies published in the IRs of the Brazilian Federal Universities, even though some of them stated the intention of preserving the collection in their IIPs. In order to move from an interest in preservation to implementing this a digital preservation policy would need to be drawn up in coordination with the staff in charge of the repository and the managers of the collections. Such a policy, would need to be approved by the highest university authorities and that would also imply the assumption of a real commitment from the institution towards digital preservation issues. A well-structured policy depends upon investment in the training of the staff, as mentioned before. In this sense, universities should establish an educational partnership with the IBICT in order to train all the participants involved in achieving this goal. The truth is that these initiatives are very important for the dissemination of a digital preservation culture among academics, especially with regard to the collection of IRs. 
We should not forget that the number of initiatives related to digital preservation policies around the world highlights the need for awareness of its importance in Brazil. In order to be coherent with the open access movement, federal universities must spread the digital preservation culture inside their own academic community, assuring the involvement of all stakeholders.

\section{Bibliography}

Beagrie, N., Semple, N., Williams, P. and Wright, R. (2008), "Digital Preservation Policies Study", available at:

http://www.jisc.ac.uk/media/documents/programmes/preservation/jiscpolicy p1finalreport.pdf (accessed 14 June 2015).

BOAI (2012), "Ten years on from the Budapest Open Access Initiative: setting the default to open", available at: http://www.budapestopenaccessinitiative.org/boai-10-recommendations (accessed 15 June 2015).

FURG (2011), "Política de Informação Institucional da FURG available at: http://repositorio.furg.br/static/politica (accessed 15 June 2015).

Harnad, S. (2006) "The Immediate-Deposit/Optional-Access (ID/OA) mandate: rationale and model. Open Access Archivangelism", available at: http://openaccess.eprints.org/index.php?/archives/71-guid.html (accessed 27 april 2016).

Hubbard, B. and Björnshauge, L. (2006), "Release of OpenDOAR listing”, available at: http://www.sherpa.ac.uk/news/opendoarlaunch.html (accessed 14 June 2015).

IBICT (2005), "Manifesto Brasileiro de Apoio ao Acesso Livre à Informação Científica", available at: http://livroaberto.ibict.br/Manifesto.pdf (accessed 14 June 2015).

InterPARES 3 (2009), "Digital Records Management/Preservation Education Modules", available at: http://www.interpares.org/ip3/ip3 general studies.cfm\#gs12 (accessed 14 June 2015).

Kuramoto, H. (2009), “Repositórios institucionais: políticas e mandados”, in Sayão, L. et al. (Eds.), Implantação e gestão de repositório institucionais: políticas, memória, livre acesso e preservação, EDUFBA, Salvador, BA, pp. 203-217.

Li, Y. and Banach, M. (2011), "Institutional Repositories and Digital Preservation: Assessing Current Practices at Research Libraries”, D-Lib Magazine, Vol. 17 No. 5/6, available at: http://www.dlib.org/dlib/may11/yuanli/05yuanli.html (accessed 27 april 2016).

Lynch, C. A. (2003), "Institutional Repositories: Essential Infrastructures for Scholarship in the Digital Age", available at: http://www.arl.org/storage/documents/publications/arl-br-226.pdf (accessed 14 June 2015).

Markey, K., Rieh, S.Y., St Jean, B., Kim, J. and Yakel, E. (2007), "Census of Institutional Repositories in the United States", available at: http://www.clir.org/pubs/reports/pub140/pub140.pdf (accessed 14 June 2015). 
McGovern, N. Y. and McKay, A. C. (2008), "Leveraging Short-term Opportunities to Address Long-term Obligations: A Perspective on Institutional Repositories and Digital Preservation Programs", available at: http://hdl.handle.net/2142/10674 (accessed 14 June 2015).

Medeiros, S. e Ferreira, P. (2014), "Política pública de acesso aberto à produção científica: um estudo sobre a implementação de repositórios institucionais em instituições de ensino superior”, Perspectivas em Gestão \& Conhecimento, Vol. 4 No. 2, pp. 195-217.

Noonan, D. W. (2014), “Digital Preservation Policy Framework: A Case Study”, available at: http://er.educause.edu/articles/2014/7/digital-preservation-policy-framework-a-case-study (accessed 15 December 2015).

OpenDOAR (2014a), “About OpenDOAR”, available at: http://www.opendoar.org/about.html (accessed 8 December 2015).

OpenDOAR (2014b), "Policies Tool”, available at: http://www.opendoar.org/tools/en/policies.php (accessed 14 June 2015).

Ribeiro, F.C. (2012), “Análise de risco: uma metodologia a serviço da preservação digital”, available at: www.ufpe.br/ppgci/images/documentos/disserta/2010\%20fanny.pdf (accessed 21 May 2015).

Rodrigues, E. (2009), "Kit de políticas open access. Repositório de Acesso Aberto Científico de Portugal", available at: http://projecto.rcaap.pt/index.php/lang-pt/consultar-recursos-deapoio/remository?func $=$ fileinfo\&id=336 (accessed 27 April 2016).

Sierman, B., Jones, C. and ElstrØm, G. (2014), "Catalogue of Preservation Policy Elements", available at: http://www.scape-project.eu/wp-content/uploads/2014/02/SCAPE D13.2 KB V1.0.pdf (accessed 14 June 2015).

Rollemberg, R. (2011), "Projeto de lei do Senado no 387 de 2011", available at: http://www.senado.gov.br/atividade/materia/detalhes.asp?p_cod_mate=101006 (accessed 14 June 2015).

Suber, P. (2013), “Open access overview: focusing on open access to peer-reviewed research articles and their preprints”, available at: http://legacy.earlham.edu/ peters/fos/overview.htm (accessed 15 June 2015).

UFBA (2010), “Repositório Institucional da UFBA - Política Institucional”, available at: https://repositorio.ufba.br/ri/about/about.jsp (accessed 15 June 2015).

UFC (2011), "Política Institucional de Informação", available at: http://www.repositorio.ufc.br/ri/sobre/Resolucao02_Consuni_2011.pdf(accessed 15 June 2015).

UFES (2015), "Repositório Institucional da UFES”, available at: http://repositorio.ufes.br/ (accessed 1 July 2015).

UFF (2015), “Repositório Institucional da UFF”, available at: http://www.repositorio.uff.br/jspui/ (accessed 1 July 2015).

UFG (2015), "Repositório da Universidade Federal de Goiás”, available at: http://repositorio.bc.ufg.br/ (accessed 1 July 2015). 
UFGD (2010), "Política Institucional para Divulgação das Produções Científicas e Técnicas da Universidade Federal da Grande Dourados", available at: http://www.ufgd.edu.br/prograd/repositorio-ufgd (accessed 27 December 2015).

UFLA (2012), "Política de Informação Institucional da UFLA", available at: http://www.ufla.br/documentos/arquivos/082_13112012.pdf (accessed 15 June 2015).

UFMA (2015), “Repositório Institucional da UFMA”, available at: http://www.repositorio.ufma.br/xmlui/ (accessed 1 July 2015).

UFMG (2015), “Repositório Digital da UFMG”, available at: https://dspaceprod02.grude.ufmg.br/dspace/ (accessed 1 July 2015).

UFOP (2013), “Política de Informação do Repositório Institucional da UFOP”, available at: http://www.repositorio.ufop.br/jspui-teste/image/5525.pdf (accessed 1 July 2015).

UFPA (2015), "Repositório Institucional da UFPA”, available at: http://www.repositorio.ufpa.br/jspui/outros/politicas.jsp?politica=preservacao (accessed 15 June 2015).

UFPB (2015), "Repositório Eletrônico Institucional”, available at: http://rei.biblioteca.ufpb.br:8080/jspui/ (accessed 15 June 2015).

UFPE (2015), “Repositório Institucional da UFPE”, available at: http://repositorio.ufpe.br/ (accessed 30 June 2015).

UFPEL (2010), "Política de Informação do Repositório Institucional Digital UFPel”, available at: http://repositorio.ufpel.edu.br/handle/ri/2644 (accessed 15 June 2015).

UFPR (2015), "Repositório Digital Institucional”, available at: http://dspace.c3sl.ufpr.br/dspace/ (accessed 1 July 2015).

UFRB (2013), "Política de Informação Técnico-Científica da UFRB”, available at: http://repositorio.ufrb.edu.br/arquivos/Portaria 771_2013.pdf(accessed 15 June 2015).

UFRGS (2010), "Portaria No 5068 de 2010”, available at: http://www.lume.ufrgs.br/arquivos_download/Portaria-5068.pdf (accessed 15 June 2015).

UFRN (2010), “Política Institucional de Informação Técnico-Científica na Universidade Federal do Rio Grande do Norte", available at:

http://repositorio.ufrn.br:8080/jspui/documentos/resolucao_592010_consepe_riufrn.pdf (accessed 15 June 2015).

UFS (2010), "Política de acesso livre à informação científica da UFS", https://ri.ufs.br/files/politica-riufs.pdf (accessed 15 June 2015).

UFSC (2015), “Repositório Institucional da UFSC”, available at: http://www.repositorio.ufsc.br/ (accessed 30 June 2015).

UTFPR (2009), "Política de Informação do Repositório Institucional da UTFPR", available at: http://repositorio.utfpr.edu.br/jspui/sobre/politica_repositorio_1.pdf (accessed 15 June 2015). 
UFU (2015), "Repositório Institucional da Universidade Federal de Uberlândia", available at: http://repositorio.ufu.br/ (accessed 1 July 2015).

UFVJM (2010), "Política de Funcionamento do Repositório Institucional da UFVJM", available at: http://acervo.ufvjm.edu.br:8080/jspui/ (accessed 15 June 2015).

UNB (2013), "Política de Informação do Repositório da Universidade de Brasília", available at: http://repositorio.unb.br/termo/resolucao.pdf (accessed 1 July 2015). 